\title{
Árangur kransæðahjáveituaðgerða á Íslandi 2002-2006
}

\author{
Hannes Sigurjónsson 1,2, Sólveig Helgadóttir1, Sæmundur J. Oddsson', Martin Ingi Sigurðsson', Arnar Geirsson', Pórarinn Arnórsson', Tómas \\ Guðbjartsson ${ }^{1,2}$
}

\section{ÁGRIP}

Inngangur: Á Íslandi hafa verið framkvæmdar um 3500 kransæðahjáveituaðgerðir, annað hvort með hjarta- og lungnavél (HLV) eða á sláandi hjarta (SH). Tilgangur rannsóknarinnar var að kanna árangur pessara aðgerða hér á landi.

Efniviður og aðferðir: Rannsóknin var afturskyggn og náði til 720 sjúklinga sem gengust undir kransæðahjáveituađgerð á Landspítala árin 2002-2006 og skiptust peir í tvo hópa; 513 einstaklinga sem gengust undir aðgerð með HLV (HLV-hópur) og 207 á SH (SH-hópur). Fylgikvillar og dánartíđni innan 30 daga voru borin saman milli hópa og forspárbættir lifunar metnir með ein- og fjölbreytugreiningu.

Niðurstöður: Karlar voru fleiri i HLV-hópi en áhættupættir kransæðasjúkdóma, aldur og líkamspyngdarstuðull reyndust sambærilegir milli hópa, einnig fjöldi æðatenginga og EuroSCORE.
Aðgerðir á sláandi hjarta stóðu 25 mínútum lengur og blæðing í brjóstholskera var marktækt aukin en magn blóðs sem var gefið var sambærilegt í báđum hópum. Minniháttar fylgikvillar voru algengari í HLV-hópi (58\% á móti $48 \%, p<0,05)$. Af alvarlegum fylgikvillum voru enduraðgerðir vegna blæðinga algengari i HLV-hópi og heildarlegutími rúmum sólarhring lengri. Dánartíðni innan 30 daga var hins vegar ápekk í báđum hópum (4\% á móti 3\%, $p=0,68$ ), einnig 5 ára lifun sem var í kringum 93\% í báđum hópum. Í fjölbreytugreiningu spáđu hærra EuroSCORE og aldur fyrir dánartíoni innan 30 daga og langtímalifun en ekki tegund aðgerðar (HLV eða SH).

Ályktanir: Árangur kransæðahjáveituaðgerða á Íslandi er góður, bæði hvað varðar dánartíðni innan 30 daga og langtímalifun. Petta á jafnt við um aðgerðir sem framkvæmdar eru með aðstoð HLV og á sláandi hjarta.
Höfundar eru öll læknar.

${ }^{1} H$ jarta- og lungnaskurðdeild Landspítala,

${ }^{2} æ k$ nadeild Háskóla Íslands.

Fyrirspurnir: Tómas Guðbjartsson

tomasgud@landspitali.is 10. apríl 2012, sampykkt til birtingar 12. ágúst 2012.

Engin hagsmunatengsl gefin upp.

\section{Inngangur}

Kransæðahjáveituaðgerðir hafa verið framkvæmdar á Íslandi síðan 14. júní 1986 pegar hjarta- og lungnavél (HLV) var notuð í fyrsta sinn hér á landi. Síðan hafa rúmlega 5500 opnar hjartaaðgerðir verið framkvæmdar á Landspítala, og eru tveir priðju pessara aðgerða kransæðahjáveituaðgerðir. ${ }^{1}$

Helsta ábending kransæðahjáveituagerðar er kransæðasjúkdómur sem tekur til allra priggja meginkransæða, sérstaklega ef um er að ræða vinstri höfuðstofnsprengsli eða prengsli ofarlega í framveggsgrein hjarta (LAD). Ávinningur af skurðaðgerð virðist vera einna mestur hjá peim sjúklingum sem eru með útbreiddan kransæðasjúkdóm og eru jafnframt með sykursýki. ${ }^{2}$ Fylgikvillar eftir kransæðahjáveituaðgerð eru tíðir, enda aðgerðirnar umfangsmiklar. ${ }^{3}$ Í flestum tilvikum er um minniháttar fylgikvilla að ræða, eins og gáttatif eða vægar skurðsýkingar, en alvarlegri fylgikvillar, eins og blæðingar sem krefjast enduraðgerðar og hjartadrep, koma einnig oft fyrir. ${ }^{4}$

Við hefðbundna kransæðahjáveituaðgerð er vinstri brjóstholsslagæð (LIMA) tengd við framveggsgrein hjartans (LAD) og bláæð frá ganglim (v. saphena magna) notuð til hjáveitu á aðrar kransæðar sem eru með marktæk prengsli sem hefta blóðflæði um pær. Oftast er notast við hjarta- og lungnavél (HLV) par sem hjartað er stöðvað í aðgerðinni með kaldri kalíumríkri lausn (cardioplegia). Kransæðahjáveituaðgerð er einnig hægt að framkvæma á sláandi hjarta (SH) (off pump coronary artery bypass, OPCAB). Er pá notast við sérhannaða gaffla sem minnka hreyfingar hjartans við pá kransæð sem unnið er við hverju sinni. Á Landspítala var byrjað að gera aðgerðir á SH upp úr 1999 samhliða aðgerðum par sem notast var við HLV. ${ }^{1}$ Niðurstöður erlendra rannsókna á pví hvor aðferðin sé betri eru misvísandi, en óumdeilt er að aðgerðir á SH eru tæknilega flóknari og taka lengri tíma. 5,6 Í fyrstu rannsóknum virtist tíðni alvarlegra fylgikvilla lægri eftir aðgerðir á SH. Petta átti sérstaklega við um fylgikvilla sem raktir voru til notkunar HLV, eins og enduraðgerða vegna blæðinga og blóðpurrðar í heila.7 Síðan hefur fjöldi slembaðra rannsókna sýnt að árangur pessara aðgerða er sambærilegur, ${ }^{8-11}$ eða jafnvel lakari. ${ }^{6}$

Á síðustu tveimur árum hafa birst í Læknablađinu nokkrar rannsóknir á árangri opinna hjartaaðgerða á Íslandi, til dæmis á áhrifum offitu á árangur kransæðahjáveituaðgerða ${ }^{12}$ og önnur par sem litið var sérstaklega á árangur hjá öldruðum. ${ }^{13}$ Ekki var skoðaður sérstaklega árangur mismunandi tegunda hjáveituaðgerða í pessum rannsóknum og forspárpættir lifunar aðallega metnir út frá aldri, hæð og pyngd sjúklinganna. Tilgangur pessarar rannsóknar var að kanna árangur hjáveituaðgerða með aðstoð HLV annars vegar og á SH hins vegar, með aðaláherslu á fylgikvilla, dánartíoni innan 30 daga og langtímalifun.

\section{Efniviður og aðferðir}

Rannsóknin var afturskyggn og náði til 720 sjúklinga sem gengust undir kransæðahjáveituaðgerð á Landspítala frá 1. janúar 2002 til 31. desember 2006. Á mynd 


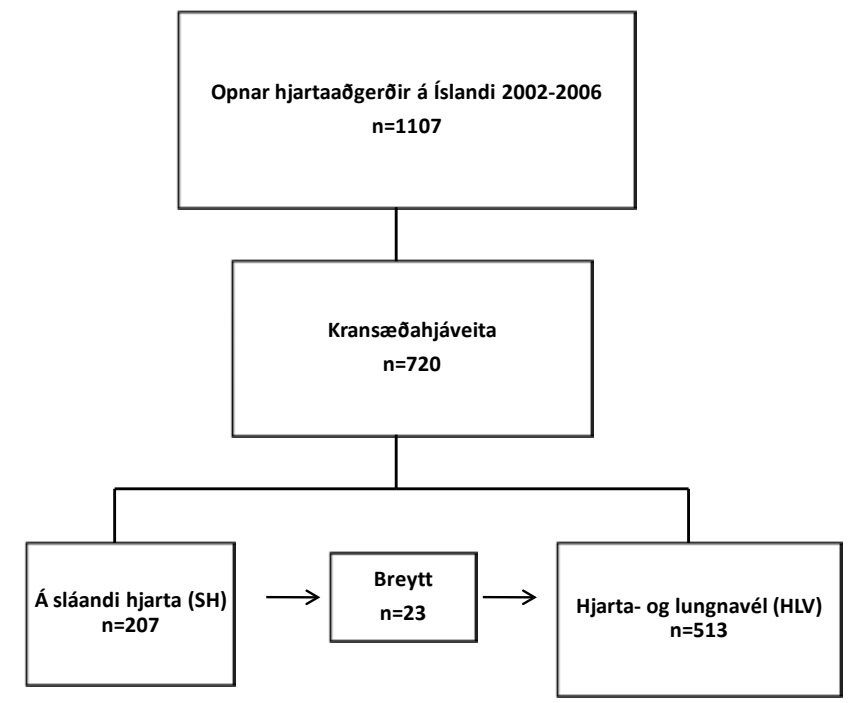

Mynd 1. Flæðirit yfir rannsóknarhópinn sem sýnir skiptingu i hópa og pá sem farðust á milli hópa.

1 er flæðirit sem sýnir rannsóknarhópinn. Sjúklingum sem gengust undir aðra hjartaaðgerð samtímis kransæðahjáveitu, eins og ósæðarlokuskipti eða míturlokuviðgerð, var sleppt. Sjúklingar voru fundnir í tveimur miðlægum skrám: annars vegar sjúklingabókhaldi Landspítala, par sem leitað var að aðgerðarnúmerum fyrir kransæðahjáveituaðgerð, og hins vegar í aðgerðaskrá hjarta- og lungnaskurðdeildar Landspítala. Til samanburðar var aflað upplýsinga um fjölda kransæðavíkkana með og án stoðnets á tímabilinu. Pessar upplýsingar fengust úr sérstökum gagnagrunni hjartapræðingadeildar Landspítala og var fjöldi peirra borinn saman við fjölda kransæðapræðinga á tímabilinu.

Klínískar upplýsingar um sjúklinga fengust úr sjúkraskrám og voru pær færðar í rafrænan gagnagrunn. Rúmlega 100 breytur voru skráðar fyrir hvern einstakling, meðal annars upplýsingar um kyn, aldur og pekkta áhættupætti kransæðasjúkdóms. Einnig var skráð hæð og pyngd allra sjúklinga og út frá peim upplýsingum reiknaður út líkamspyngdarstuðull. Athugað var hvort sjúklingarnir höfðu sögu um kransæðastíflu eða hjartsláttaróreglu og hvaða hjartalyf peir tóku fyrir aðgerðina. Útbreiðsla kransæðasjúkdóms var metin samkvæmt hjartapræðingu og skráð hvort um var að ræða priggja æða kransæðasjúkdóm eða vinstri höfuðstofnsprengsli.

Farið var yfir ómsvör fyrir aðgerð og meðal annars skráð útstreymisbrot vinstri slegils (left ventricular ejection fraction, LVEF). Einkenni hjartabilunar voru metin samkvæmt NYHA flokkun (New York Heart Association) og staðlað EuroSCORE (European
System for Cardiac Operative Risk Evaluation) reiknað út fyrir alla sjúklinga en pað er alpjóðlega viðurkennt áhættumat fyrir hjartaskurðaðgerðir.

Sjúklingunum 720 var skiptí tvo hópa eftir pvíhvort aðgerðirnar voru framkvæmdar með aðstoð HLV (HLV-hópur, n=513) eða á SH (SH-hópur, n=207) (mynd 1). Alls var 23 aðgerðum á sláandi hjarta breytt yfir í hefðbundna aðgerð með HLV en við útreikninga eru pær taldar með SH-hópnum (intention-to-treat). Aðgerð var skilgreind sem bráðaaðgerð ef hún var ákveðin og framkvæmd innan sólarhrings frá pví að sjúklingur lagðist á sjúkrahús.

Allar aðgerðirnar voru framkvæmdar í gegnum bringubeinsskurð. Skráður var aðgerðartími í mínútum (skin-to-skin) en einnig hvort um val- eða bráðaaðgerð var að ræða. Í HLV-hópi var sett töng á ósæðina, hjartað stöðvað með kalíumríkri lausn (cardioplegia) og fjartengingar á kransæðar gerðar með hjartað stöðvað í vægri líkamskælingu (um pað bil $35^{\circ} \mathrm{C}$ ). Hjá pessum sjúklingum var skráđur tangartími (aortic cross-clamp time) og tími á HLV. Við aðgerð á sláandi hjarta var notast við sérstaka haka og gaffla með sogskálum (Medtronic Inc., Minneapolis, MN, USA) til að upphefja hreyfingar hjartans. Pegar græðlingur var saumaður við kransæðina var kransæðinni annaðhvort lokað tímabundið með lykkjusaumum eða plaströri komið fyrir í æðinni og pað síðan dregið út áður en tengingunni var lokað.

Fylgikvillar voru skráðir 30 daga eftir aðgerð og lengur ef sjúklingar lágu enn á sjúkrahúsi. Peir voru nánar flokkaðir í alvarlega fylgikvilla (heilablóðfall, sýking í bringubeini, blóðpurrð í hjarta, nýrnaskaði sem krafðist blóðskilunar, enduraðgerð vegna blæðingar og fjöllíffærabilun) og minniháttar fylgikvilla (gáttatif/flökt, yfirborðssýking í skurðsári, nýrnaskaði sem ekki krafðist skilunar, lungnabólga, pvagfærasýking og aftöppun fleiðruvökva). Blóðpurrð í hjartavöðva var skilgreind sem nýtilkomnar SThækkanir eða vinstra greinrof á hjartalínuriti ásamt hækkun á CK-MB hjartaensíminu yfir $75 \mu \mathrm{g} / \mathrm{L}$. RIFLE-skilmerki voru notuð til að meta nýrnastarfsemi og sjúklingar í áhættu ( $\mathrm{R}=$ risk), skaða(I=injury) eða bilunarflokki ( $\mathrm{F}=$ failure) skilgreindir með bráðan nýrnaskaða.

Skráð var blæðing í brjóstholskera fyrstu 24 klukkustundirnar eftir aðgerð og fjöldi eininga af rauðkornapykkni sem sjúklingnum voru gefnar í eða eftir aðgerðina. Skurðdauði (operative mortality) var skilgreindur sem andlát innan 30 daga frá aðgerð.

Langtímaeftirfylgd byggði á dánarupplýsingum frá Hagstofu og voru skráð dánardægur fram til 31. desember 2009. Meðaleftirfylgd var 60,4 mánuðir (bil 0-96). Við útreikninga á aldursstöðluðum fjölda aðgerða á rannsóknartímabilinu var stuðst við mannfjöldaupplýsingar frá Hagstofu.

Tafla I. Fjöldi kransæðahjáveituaðgerða sem gerðar voru á Íslandi frá 2002 til 2006. Einnig er sýnt hlutfall aðgerða sem framkvæmdar voru á sláandi hjarta. Til samanburðar er sýndur fjöldi kransæðavíkkana á sama tímabili og hlutfall sjúklinga sem fengu að̃ minnsta kosti eitt stoðnet í kransæðar. Fjöldi (\%).

\begin{tabular}{|c|c|c|c|c|c|c|}
\hline Ár & 2002 & 2003 & 2004 & 2005 & 2006 & Samtals \\
\hline Fjöldi kransæðapræðinga & 1493 & 1630 & 1497 & 1674 & 1526 & 7820 \\
\hline 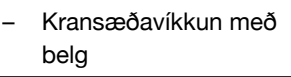 & $568(38)$ & $624(38)$ & $556(37)$ & $636(38)$ & $610(40)$ & $2994(38)$ \\
\hline - Stoðnet & $474(32)$ & $531(33)$ & $468(31)$ & $570(34)$ & $533(35)$ & $2576(33)$ \\
\hline $\begin{array}{l}\text { Fjöldi kransæðahjáveitu- } \\
\text { aðgerða }\end{array}$ & 153 & 139 & 133 & 156 & 139 & 720 \\
\hline $\begin{array}{l}\text { - } \text { Með aðstoð hjarta- og } \\
\text { lungnavélar }\end{array}$ & $117(76)$ & $103(74)$ & $85(64)$ & $107(69)$ & $101(27)$ & $513(71)$ \\
\hline - Á sláandi hjarta & $36(24)$ & $36(26)$ & $48(36)$ & $49(31)$ & $38(73)$ & 207 (29) \\
\hline
\end{tabular}



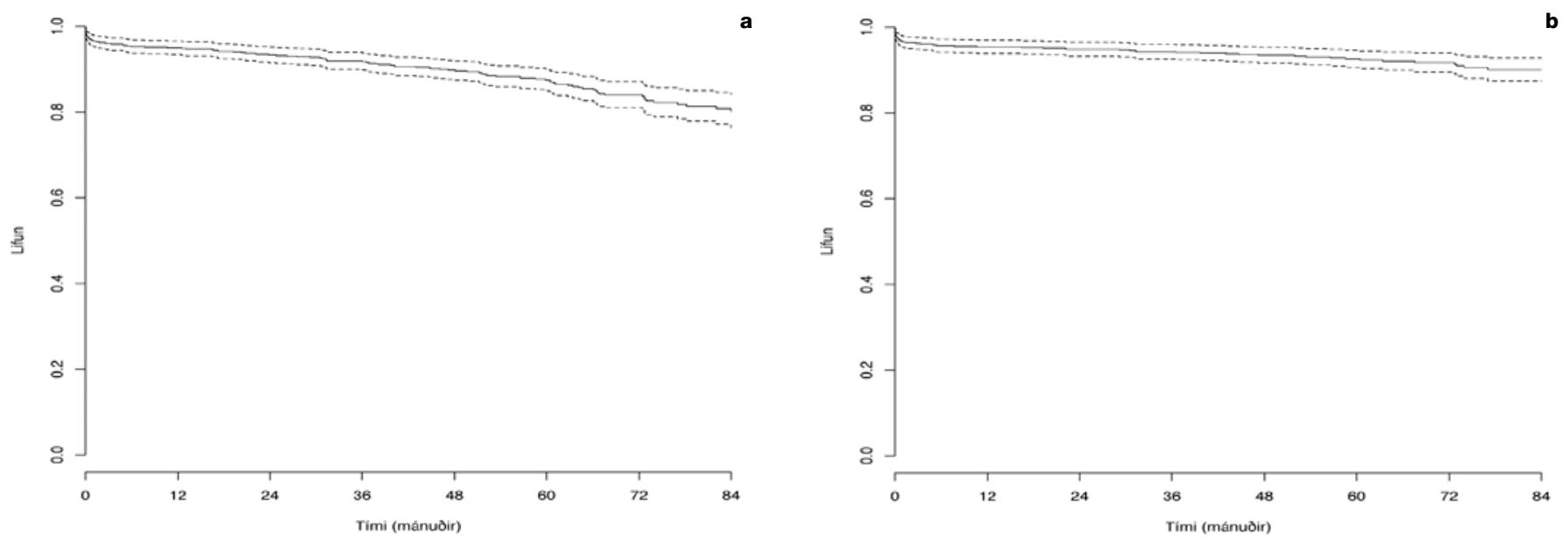

Mynd 2. Heildar- (a) og sjúkdómasértæk lifun (b) sjúklinga sem gengust undir kransæðahjáveituaðgerð á Íslandi 2002-2006. Lífshorfur eru sýndar saman fyrir sjúklinga sem gengust undir aðgerð með HLV og SH. Einnig eru sýnd 95\% öryggismörk (brotnar línur).

Breytur voru skráðar í forritið Excel (Microsoft Corp, Redmond, WA) og pað notað við lýsandi tölfræði. Allir tölfræðiútreikningar voru gerðir í $\mathrm{R}$, útgáfu 2.5.10 ( $\mathrm{R}$ foundation for Statistical Computing, Vín, Austurríki) og miðast marktæki við p gildi $<0,05$. Við samanburð hópa var notast við t-próf fyrir samfelldar breytur og Fischer Exact eða kí-kvaðrat próf fyrir hlutfallsbreytur. Par sem dreifing aðgerðartíma og blæðingar eftir aðgerð var skekkt voru pessar breytur bornar saman með Wilcoxon ranked sum-prófi sem ekki krefst normaldreifingar. Aðferð Kaplan-Meier var notuð til að áætla bæði heildarlifun (overall survival) og sjúkdómasértæka lifun (disease specific survival) og voru dánarorsakir skráðar samkvæmt dánarvottorðum. Forspárpættir skurðdauða voru metnir með lógistískri aðhvarfsgreiningu og forspárpættir langtímalifunar voru metnir með fjölbreytugreiningu Cox par sem leiðrétt var fyrir bjagandi breytum á borð við aldur og EuroSCORE. Allar breytur í endanlega líkaninu stóðust kröfu um hlutfallsbil (proportionality).

Áður en rannsóknin hófst fengust öll tilskilin leyfi frá Vísindaog siðanefnd, Persónuvernd og frá framkvæmdastjóra lækninga á Landspítala.

\section{Niðurstödur}

Alls voru gerðar 720 aðgerðir, 513 á HLV og 207 á SH og voru karlar $591(82 \%)$ og konur 129 (18\%). Á peim 5 árum sem rannsóknin náði til voru að meðaltali gerðar 144 kransæðaaðgerðir á ári (bil 133-153) sem gefur nýgengi 49/100.000 á ári fyrir allt tímabilið. Tæpur priðjungur (29\%) aðgerðanna voru gerðar á SH, flestar árið 2004 (36\%) en fæstar árið 2002 (24\%) (tafla I). Tafla I sýnir samanburð á fjölda kransæðaaðgerða og kransæðavíkkana á rannsóknartímabilinu og hlutfall sjúklinga sem fengu stoðnet. Að meðaltali gengust 599 sjúklingar undir kransæðavíkkun árlega og fengu $86 \%$ peirra að minnsta kosti eitt stoðnet í kransæðar. Ekki urðu marktækar breytingar í fjölda kransæðahjáveituaðgerða á tímabilinu né heldur fjölda kransæðavíkkana með eða án stoðnets $(\mathrm{p}>0,1)$.

Í töflu II sést samanburður á sjúklingum í SH- og HLV-hópi. Meðalaldur var sambærilegur í hópunum en karlar voru marktækt fleiri í HLV-hópi. Algengi áhættupátta kransæðasjúkdóms, par á meðal háprýstings, sykursýki og blóðfituröskunar var sú sama í báðum hópum, sömuleiðis líkamspyngdarstuðull, notkun
Tafla II. Samanburður á sjúklingum sem gengust undir kransæðahjáveituaðgerð á Landspítala 2002-2006, bæði aðgerðir á sláandi hjarta (SH-hópur) og með hjartaog lungnavél (HLV-hópur). Fjöldi (\%) eða međaltöl með staðalfráviki.

\begin{tabular}{|c|c|c|c|c|}
\hline Breyta & $\begin{array}{c}\text { Allir } \\
\text { sjúklingar } \\
n=720\end{array}$ & $\begin{array}{l}\text { SH-hópur } \\
\qquad n=207\end{array}$ & $\begin{array}{c}\text { HLV- } \\
\text { hópur } \\
n=513\end{array}$ & p-gildi \\
\hline Aldur, ár \pm stfv. & $66,4 \pm 9,3$ & $66,4 \pm 9,2$ & $66,4 \pm 9,3$ & 0,95 \\
\hline Karlkyn & $591(82)$ & $160(77)$ & $431(84)$ & 0,04 \\
\hline \multicolumn{5}{|c|}{ Áhættupættir kransæðasjúkdóms } \\
\hline Háprýstingur & $443(60)$ & $130(61)$ & $313(63)$ & 0,73 \\
\hline Sykursýki & $109(15)$ & $29(14)$ & $80(16)$ & 0,67 \\
\hline Blóðfituhækkun & $421(58)$ & $120(58)$ & $301(58)$ & 0,93 \\
\hline Saga um reykingar & $174(24)$ & $45(22)$ & $129(25)$ & 0,37 \\
\hline $\begin{array}{l}\text { Líkamspyngdarstuðull } \\
\left(\mathrm{kg} / \mathrm{m}^{2}\right)\end{array}$ & 28,0 & $28,2 \pm 4,2$ & $27,9 \pm 4,1$ & 0,37 \\
\hline \multicolumn{5}{|c|}{ Lyf tekin <5 dögum fyrir aðgerð } \\
\hline Hjartamagnýl & $513(71)$ & $150(72)$ & $363(71)$ & 0,71 \\
\hline Blóðfitulækkandi statín & $529(73)$ & $148(71)$ & $381(74)$ & 0,50 \\
\hline Beta blokkerar & $482(67)$ & $141(68)$ & $341(66)$ & 0,74 \\
\hline $\begin{array}{l}\text { Priggja æða } \\
\text { hjartasjúkdómur }\end{array}$ & $628(87)$ & $176(85)$ & $452(88)$ & 0,32 \\
\hline $\begin{array}{l}\text { Prengsli í vinstri } \\
\text { höfuðstofni }\end{array}$ & $152(21)$ & $44(21)$ & $108(21)$ & 0,97 \\
\hline Útfallsbrot hjarta $<35 \%$ & $59(8)$ & $17(8)$ & $42(8)$ & 0,89 \\
\hline Lungnateppa (COPD) & $55(8)$ & $14(7)$ & $41(8)$ & 0,70 \\
\hline NYHA flokkur III eða IV & 499 (69) & $160(77)$ & $339(66)$ & 0,004 \\
\hline EuroSCORE (st.) & $4,9 \pm 3,3$ & $5,2 \pm 3,5$ & $4,8 \pm 3,2$ & 0,23 \\
\hline
\end{tabular}

COPD = chronic obstructive pulmonary disease

hjartalyfja fyrir aðgerð og EuroSCORE. Hins vegar voru marktækt fleiri sjúklingar í SH-hópi í NYHA-flokki III og IV.

Alls var 23 aðgerðum á sláandi hjarta breytt í hefðbundna aðgerð með HLV, og voru algengustu ástæðurnar lágur blóðprýstingur pegar hjartanu var lyft (n=15), erfiðleikar við að komast að kransæðum á bakvegg hjartans $(\mathrm{n}=6)$ eða kransæðar staðsettar djúpt í hjartavöðva $(\mathrm{n}=2)$.

Í töflu III eru upplýsingar um aðgerðirnar og legutíma eftir aðgerð, auk blæðingarmagns í brjóstholskera. Bráðaaðgerðir voru 
25 talsins (4\%) en ekki var marktækur munur á milli hópa, eða

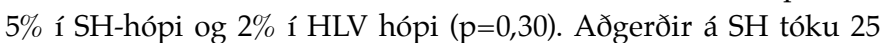
mínútum lengri tíma $(\mathrm{p}<0,001)$. Tangartími var 43 mínútur hjá sjúklingum í HLV-hópi og meðaltími á HLV var 85 mínútur. Blæðing í brjóstholskera eftir aðgerð var aukin um $274 \mathrm{~mL}$ í SHhópi ( $\mathrm{p}=0,001)$ en fjöldi eininga (miðgildi) af rauðkornapykkni sem gefinn var í eða eftir aðgerð sambærilegur (2,5 sbr. 2,4 ein., $\mathrm{p}=0,84)$. Enduraðgerðir vegna blæðinga voru hins vegar fleiri 1 HLV-hópnum, eða $6 \%$ borið saman við $4 \%$ ( $\mathrm{p}=0,02)$.

Sjúklingarnir íbáđum hópum lágu að meðaltali í tvo sólarhringa á gjörgæslu en að miðgildi einn sólarhring. Heildarlegutími sjúklinga í HLV-hópi var að meðaltali ríflega sólarhring lengri en peirra í SH-hópi (12,5 sbr. 11,3 dagar, p=0,04). Miðgildi heildarlegutíma var 10 í báđum hópum, bil 1-96 í HLV-hópi og 1-42 í SH-hópi.

Fylgikvillar eftir aðgerð eru sýndir í töflu IV. Ekki reyndist munur á heildartíðni alvarlegra fylgikvilla. Heildartíðni minniháttar fylgikvilla var hærri í í HLV- hópi, eða 58\% borið saman við 48\% í SH-hópi ( $\mathrm{p}=0,05)$. Tíðni gáttaflökts var sambærileg, 39\% í SH-hópi og 42\% í HLV-hópi ( $\mathrm{p}=0,5)$.

Alls létust 22 sjúklingar innan 30 daga og var skurðdauði pví $3,2 \%$. Skurðdauði var sambærilegur fyrir sjúklinga í HLV- og SH-hópi (3\% á móti 4\%, $\mathrm{p}=0,68$ ). Algengustu dánarorsakir voru hjartadrep fyrir aðgerð (bráðaaðgerðir) (n=7), hjartadrep vegna lokunar á æðagræðlingum $(\mathrm{n}=6)$, hjartabilun án hjartadreps í aðgerð (n=5), mikil blæðing í eða eftir aðgerð $(n=2)$, öndunarbilun $(n=1)$ og fjöllíffærabilun ( $n=1)$. Skurðdauði fyrir sjúklinga par sem aðgerð á SH var breytt í aðgerð á HLV var 22\% (5/23) en tveir sjúklingar til viðbótar dóu eftir 30 daga sjúkrahússlegu.

Á mynd 2 sést lifun sjúklinga eftir aðgerð, bæði heildarlifun og sjúkdómasértæk og eru báđir hópar sýndir saman. Sjúkdómasértæk lifun eftir eitt og fimm ár var 96\% og 92\% fyrir HLV-hópinn og 95\% og 93\% fyrir SH-hópinn. Ekki var marktækur munur á lifun eftir tegund aðgerðar $(\mathrm{p}=0,87)$.

Fjölpáttagreining (logistic regression) á áhættupáttum skurðdauða fyrir báđa hópana saman sýndi að EuroSCORE (líkindahlutfall (LH) 1,64, 95\% öryggisbil (ÖB): 1,2-2,3, p=0,003) var sterkasti sjálfstæði forspárpáttur aukins skurðdauða en einnig hærri aldur (LH 1,21, 95\% ÖB: 1,03-1,42, p=0,02). Sjúklingar sem tóku blóðfitulækkandi statín fyrir aðgerð höfðu hins vegar marktækt betri lifun en peir sem ekki voru á statínum fyrir aðgerð ( $\mathrm{LH} \mathrm{0,24,}$ 0,06-0,94, p=0,04) og voru pau pví verndandi.

Tegund aðgerðar hafði hvorki forspárgildi fyrir skurðdauða né langtímalifun (áhættuhlutfall (ÁH) 0,69, 95\% ÖB: 0,43-1,10, $\mathrm{p}=0,12$ ). Marktækir forspárpættir verri lifunar voru hins vegar hærra EuroSCORE (ÁH 1,16, 95\% CI: 1,09-1,23, p<0,0001), hærri aldur (ÁH 1,06, 95\% ÖB: 1,03-1,09, p<0,0001) og hærra CKMB-gildi eftir aðgerð (ÁH 1,02, 95\% ÖB: 1,00-1,03, p=0,05). Hærra útfallsbrot vinstri slegils var hins vegar verndandi (ÁH 0,97, 95\% ÖB: 0,95$0,98, \mathrm{p}=0,0002)$.

\section{Umræða}

Pessi rannsókn sýnir að dánarhlutfall innan 30 daga eftir kransæðahjáveituaðgerð var 3\%, og reyndist svipað fyrir aðgerðir á SH og með HLV. Petta verður að teljast lágt dánarhlutfall, ekki síst par sem teknar voru með bráðaaðgerðir, par með taldar aðgerðir á 5 sjúklingum í losti vegna bráðs hjartadreps. Erlendis er
Tafla III. Samanburður á aðgerðum, sjúkrahúsdvöl og dánartíðni innan 30 daga hjá sjúklingum sem gengust undir kransæðahjáveituaðgerð með aðstoð hjarta- og lungnavélar (HLV-hópur) og á sláandi hjarta (SH-hópur) á Landspítala.

\begin{tabular}{|c|c|c|c|c|}
\hline Breyta & $\begin{array}{c}\text { Allir } \\
\mathrm{n}=720\end{array}$ & $\begin{array}{l}\text { SH-hópur } \\
\mathrm{n}=207\end{array}$ & $\begin{array}{l}\text { HLV-hópur } \\
n=513\end{array}$ & p-gildi \\
\hline Bráðaaðgerð (\%) & $25(4)$ & $10(5)$ & $15(3)$ & 0,30 \\
\hline $\begin{array}{l}\text { Aðgerðartími, mín. } \pm \text { stfr. } \\
\text { (bil) }\end{array}$ & $204 \pm 52$ & $\begin{array}{l}223 \pm 59 \\
(85-460) \\
\end{array}$ & $\begin{array}{l}197 \pm 47 \\
(90-555)\end{array}$ & $<0,001$ \\
\hline $\begin{array}{l}\text { Fjöldi æðatenginga, stfr. } \\
\text { (bil) }\end{array}$ & 3,4 & $\begin{array}{l}3,5 \pm 0,9 \\
\quad(1-6)\end{array}$ & $\begin{array}{l}3,3 \pm 0,8 \\
\quad(1-5)\end{array}$ & 0,06 \\
\hline $\begin{array}{l}\text { Blæðing eftir aðgerð <24 } \\
\text { klst., ml. } \pm \text { stfr. (bil) }\end{array}$ & 1037 & $\begin{array}{l}1230 \pm 740 \\
(230-5620)\end{array}$ & $\begin{array}{r}960 \pm 1530 \\
(100-31820)\end{array}$ & $\begin{array}{l}<0,001 \\
<0,001\end{array}$ \\
\hline $\begin{array}{l}\text { Blóðgjafir, einingar } \pm \text { stfr. } \\
\text { (bil) }\end{array}$ & 2,5 & $\begin{array}{c}2,4 \pm 3,7 \\
(0-31)\end{array}$ & $\begin{array}{c}2,5 \pm 5,5 \\
(0-88)\end{array}$ & 0,84 \\
\hline $\begin{array}{l}\text { Enduraðgerð v/ blæðingar, } \\
\mathrm{n}(\%)\end{array}$ & $42(6)$ & $9(4)$ & $33(6)$ & 0,02 \\
\hline $\begin{array}{l}\text { Lega á gjörgæslu, dagar } \\
\pm \text { stfr. }\end{array}$ & 2,0 & $1,9 \pm 2,7$ & $2,1 \pm 3,7$ & 0,47 \\
\hline $\begin{array}{l}\text { Heildardvöl á sjúkrahúsi, } \\
\text { dagar } \pm \text { stfr. }\end{array}$ & 12,1 & $11,3 \pm 4,9$ & $12,5 \pm 6,9$ & 0,04 \\
\hline Dánartíðni < 30 daga, n (\%) & $23(3)$ & $8(4)$ & $15(3)$ & 0,68 \\
\hline
\end{tabular}

dánarhlutfall innan 30 daga oftast á bilinu 2-5\% $\%^{14}$, enda pótt lægra hlutfalli hafi verið lýst. ${ }^{15}$ Í sænska hjartagrunninum Swedeheart var dánarhlutfall 4168 kransæðahjáveitusjúklinga árið 2006 1,8\%15 og $3 \%$ í bandaríska STS-grunninum (Society of Thoracic Surgeons) sem nær til rúmlega 500.000 sjúklinga. ${ }^{16}$

Líkt og fyrir aðrar hjartaaðgerðir er tíðni fylgikvilla há eftir kransæðahjáveituaðgerð. ${ }^{3}$ Gáttatif eftir aðgerð var algengasti fylgikvillinn í báðum hópum, eða ríflega 40\% sem er í hærra lagi miðað við erlendar rannsóknir par sem hlutfall gáttatifs er oftast á bilinu 20-50\%.1718 Af alvarlegum fylgikvillum var hjartadrep sem tengdist aðgerð algengast, eða í kringum 12\%, sem er heldur hærra en lýst hefur verið í öðrum rannsóknum. ${ }^{11}$ Við samanburð verður pó að hafa í huga að skilgreining á hjartadrepi er breytileg eftir rannsóknum, sem hefur áhrif á tíðni pess. Í okkar rannsókn var miðað við CK-MB hækkun yfir $75 \mu \mathrm{g} / \mathrm{L}$ samhliða nýjum STbreytingum, Q-tökkum eða nýju vinstra greinrofi, sem er víðari skilgreining en í mörgum öðrum rannsóknum. Tíðni heilablóðfalla innan 30 daga var hins vegar lág, eða $2 \%$, sem er sambærilegt við nýlega danska rannsókn sem tók til 25.000 sjúklinga. ${ }^{19}$ Tíðni djúpra sýkinga í bringubeinsskurði (1\%) var einnig sambærileg við aðrar rannsóknir en pær hafa nýlega verið rannsakaðar hér á landi. ${ }^{20}$

Enduraðgerðir vegna blæðingar voru gerðar hjá 6\% sjúklinga. Petta er umtalsvert lægri tíðni en sást í nýlegri rannsókn eftir ósæðarlokuskipti en par voru enduraðgerðir gerðar í 17\% tilfella. ${ }^{21}$ Blæðingar sem krefjast enduraðgerðar auka tíðni fylgikvilla og skurðdauða ${ }^{22}$ og reyndust algengari í HLV- en SH-hópi. Svipuðum niðurstöðum hefur verið lýst í fjölda rannsókna, og er skýringin talin vera storkuletjandi áhrif HLV á bæði blóðflögur og magnakerfið (complement system). Í nýlegum slembirannsóknum hefur komið í ljós að munur á tíðni enduraðgerða eftir aðgerðartegund er lægri ${ }^{11,22}$ og áhrif HLV á blæðingar minni en talið var í fyrstu.

prátt fyrir aukningu enduraðgerða í HLV-hópnum er athyglisvert að meðalblæðing í brjóstholskerum eftir aðgerð var $300 \mathrm{ml}$ meiri íSH-hópnum. Petta virðist pó ekki hafa áhrif á tíðni blóðgjafa sem voru sambærilegar í báđum hópum. Skýringin á aukinni 
Tafla IV. Samanburður á alvarlegum og minniháttar fylgikvillum hjá sjúklingum sem gengust undir kransæðahjáveituaðgerð á Landspítala 2002-2006, með aðstoð hjarta- og lungnavéldar eđa á sláandi hjarta.

\begin{tabular}{lcccc} 
& Allir & SH-hópur & $\begin{array}{c}\text { HLV- } \\
\text { hópur }\end{array}$ & p-gildi \\
& $n=720$ & $n=207$ & $n=513$ & \\
\hline Alvarlegir fylgikvillar & $118(16)$ & $33(16)$ & $85(17)$ & 0,44 \\
\hline Heilablóðfall & $16(2)$ & $5(2)$ & $11(2)$ & 0,79 \\
\hline $\begin{array}{l}\text { Miðmætissýking/ } \\
\text { bringubeinssýking }\end{array}$ & $6(1)$ & $1(0,5)$ & $5(1)$ & 0,84 \\
\hline $\begin{array}{l}\text { Nýrnaskaði par sem pörf } \\
\text { er á skilun }\end{array}$ & $12(2)$ & $3(1)$ & $9(2)$ & 0,97 \\
\hline $\begin{array}{l}\text { Hjartadrep í eða eftir } \\
\text { aðgerð }\end{array}$ & $9513)$ & $23(11)$ & $72(14)$ & 0,35 \\
\hline $\begin{array}{l}\text { Fjöllíffærabilun } \\
\text { Bringubeinslos }\end{array}$ & $23(3)$ & $5(2)$ & $18(4)$ & 0,60 \\
\hline Minniháttar fylgikvillar & $19(3)$ & $3(1)$ & $16(3)$ & 0,31 \\
\hline $\begin{array}{l}\text { Gáttatif/gáttaflökt } \\
\text { Húðsýking (á fæti eða }\end{array}$ & $294(41)$ & $80(39)$ & $214(42)$ & 0,50 \\
\hline brjóstholsskurði) & $65(9)$ & $16(9)$ & $49(10)$ & 0,53 \\
\hline $\begin{array}{l}\text { Lungnabólga } \\
\text { Pvagfærasýking }\end{array}$ & $45(6)$ & $10(5)$ & $35(7)$ & 0,41 \\
\hline
\end{tabular}

blæðingu í SH-hópi er ekki augljós. Svipuðum niðurstöðum hefur verið lýst áđur, en flestar rannsóknir hafa pó sýnt minni blæðingu eftir aðgerðir á SH. ${ }^{11,23}$ Í SH-hópi var hlutfall bráðaaðgerða (sjúklingar skornir upp innan 24 klst.) hærra en í HLV-hópi (5\% á móti $2 \%$ ) en pessir sjúklingar voru nær undantekningarlaust á blóðflöguletjandi eða blóðpynnandi meðferð. Hluti sjúklinga í HLV-hópi fékk aprótínín $\left(\right.$ Trasylol $^{\circledR}$ ) í aðgerð sem gæti hafa minnkað blæðingu í peim hópi, enda pótt áhrif pess séu umdeild og lyfið hafi nú verið tekið af markaði. Hugsanleg skýring er að blóðpynning sjúklinga eftir aðgerðir á SH hafi verið of mikil, en á Landspítala fengu pessir sjúklingar auk acetýlsalicýlsýru (75 mg daglega, ævilangt), $500 \mathrm{ml}$ dextran-lausn í æð (Rheomacrodex ${ }^{\circledR}$ ) í prjá daga eftir aðgerð, lágskammta léttheparín tvisvar á dag í viku og klópídógrel (Plavix ${ }^{\circledR}$ ) (75mg x 1 daglega í mánuð eftir aðgerð). Til samanburðar var sjúklingum í HLV-hópi aðeins gefin acetýlsalicýlsýra og léttheparín en hvorki dextran-lausn né klópídógrel. Loks má nefna að hluti af peim vökva sem tæmist í brjóstholskera eftir aðgerðir á SH er skolvökvi vegna blóðsparandi sogs $\left(\right.$ Cellsaver $\left.^{\circledR}\right)$. Petta sog er alltaf notað í aðgerðum á SH hér á landi en hefur ekki verið notað í aðgerðum með HLV. Pessi skolvökvi er pó að hámarki $150 \mathrm{ml}$ og pótt petta magn sé dregið frá er samt næstum $150 \mathrm{ml}$ munur á blæðingu í hópnum, sem er marktækur munur.

Fjöldi hjartaaðgerða á Íslandi hefur aukist jafnt og pétt frá pví fyrsta aðgerðin var gerð fyrir rúmum aldarfjórðungi, og í dag hafa hátt í 6000 aðgerðir verið gerðar hér á landi. Fjöldi kransæðahjáveituaðgerða hélst nokkuð jafn á rannsóknartímabilinu, eða í kringum 144 aðgerðir á ári (49/100.000 íbúa á ári). Líkt og á flestum hinna Norðurlandanna eru kransæðahjáveituaðgerðir í kringum prír fjórðu hlutar opinna hjartaaðgerða ${ }^{1}$ en í Svípjóð er hlutfallið aðeins lægra, eða um 63\%. Árið 2006 voru gerðar 44 aðgerðir á hverja 100.000 íbúa í Svípjóð en par hefur aðgerðum fækkað síðastliðin ár, úr 63 aðgerðum á 100.000 íbúa árið 2002. ${ }^{15}$ Er pessi próun fyrst og fremst rakin til aukinnar tíðni kransæðavíkkana og ísetn- ingar kransæðastoðneta. Hvorki urðu marktækar breytingar á fjölda hjartapræðinga né fjölda kransæðahjáveituaðgerða á Íslandi á rannsóknartímabilinu.

Aðgerðir á SH eru algengar á Íslandi (29\%) miðað við nágrannalöndin, til samanburðar voru pær aðeins 2,5\% kransæðahjáveituaðgerða í Svípjóð árið 2006. ${ }^{15}$ Hlutfall pessara aðgerða getur pó verið mjög breytilegt eftir stofnunum innan sama lands. Í gagnagrunni brjóstholsskurðlækna í Bandaríkjunum (STS-database, The Society of Thoracic Surgeons) var hlutfallið aðeins 25,4\% árið 2009 samanborið við 36,6\% árið 2007..24

Samtals var 23 aðgerðanna (11\%) á SH breytt yfir í hefðbundna aðgerð með HLV, oftast vegna blóðprýstingsvandamála eða erfiðleika við að komast að kransæðum á undirvegg hjartans. Erlendis er petta hlutfall oft á bilinu 5-15\% enda pótt lægra hlutfalli $\left(3,7 \%\right.$ ) hafi verið lýst. ${ }^{10,25}$ Í upphafi rannsóknartímabilsins, á árinu 2002, höfðu aðgerðir á SH verið framkvæmdar um priggja ára skeið á Landspítala og peir skurðlæknar sem framkvæmdu aðgerðirnar pví komnir með töluverða reynslu í að framkvæma pær. Aðgerðir á SH pykja tæknilega flóknari og lengri tíma tekur að ná tökum á peim en hefðbundinni kransæðahjáveituaðgerð. ${ }^{6}$ Pví kemur ekki á óvart að aðgerðir á SH taki lengri tíma, en í okkar rannsókn munaði 25 mínútum og er pað í samræmi við stærri rannsóknir. ${ }^{6}$

Legutími á gjörgæslu var einn sólarhringur (miðgildi) og ekki munur á hópum. Hins vegar munaði einum sólarhring á heildarlegutíma, SH hópi í vil, sennilega vegna lægri tíðni minniháttar fylgikvilla. Sjúkrahúsdvöl er frekar löng á Íslandi ${ }^{10}$, en erlendis eru sjúklingar oft sendir á sjúkrahótel eða á önnur sjúkrahús eftir útskrift. Engu að síður er ljóst að mikilvægt er að stytta legutíma eftir pessar aðgerðir, enda kostar meðallegudagur á Landspítala um 104.000 kr. (desember 2011).

Sterkustu sjálfstæðu forspárpættir langtímalifunar voru aldur og EuroSCORE. Sjúkdómasértæk 5 ára lifun var yfir 92\% fyrir báða hópa og er pað í samræmi við lifun eftir pessar aðgerðir í nágrannalöndum okkar. ${ }^{15}$

Styrkur pessarar rannsóknar er að hún tekur til allra sjúklinga sem gengust undir kransæðahjáveituaðgerð hjá heilli pjóð á 5 ára tímabili. Aðeins 5 skurðlæknar framkvæmdu aðgerðirnar og nákvæmar upplýsingar fengust um afdrif allra sjúklinga sem voru fundnir með leit í tveimur aðskildum skrám. Helsti veikleiki rannsóknarinnar er að hún er afturskyggn og auk pess óslembuð. Hún er pví ekki hönnuð til að svara pví hvort aðgerðir á SH séu betri en aðgerðir með HLV. Til pess hefði purft mun fleiri sjúklinga sem æskilegt hefði verið að slemba í aðgerð með HLV og á SH. Pessi rannsókn bendir engu að síður til pess að árangur beggja aðgerða sé góður hér á landi, hvort sem litið er á snemmkomna fylgikvilla, skurðdauða eða langtímalifun. Pótt rannsóknin sé ekki slembuð gerðu tveir skurðlæknar flestar aðgerðanna á SH og hinir prír með aðstoð HLV. Hóparnir voru býsna sambærilegir og fjöldi æðatenginga sá sami, eða 3,5 tengingar að meðaltali. Í erlendum rannsóknum eru kransæðatengingar hins vegar yfirleitt færri hjá sjúklingum sem gangast undir aðgerð á $\mathrm{SH}$, sem getur skekkt niðurstöður peim aðgerðum í vil. ${ }^{10}$

Pessi rannsókn sýnir að dánartíðni eftir kransæðahjáveitu á Íslandi er lág og tíðni flestra fylgikvilla sambærileg við erlendar rannsóknir. Petta á bæði við um aðgerðir á sláandi hjarta og með aðstoð hjarta- og lungnavélar. 


\section{Pakkir}

Pakkir fær Gunnhildur Jóhannsdóttir fyrir aðstoð við leit að sjúkraskrám, Sigurlaug Magnúsdóttir fyrir upplýsingar um fjölda kransæðavíkkana og Sigurjón H. Ólafsson fyrir yfirlestur.
Rannsóknin var styrkt af Vísindasjóði Landspítala, Minningarsjóði Bengt Scheving Thorsteinssonar, Rannsóknarsjóði Háskóla Íslands og Minningarsjóði Helgu Guðmundsdóttur og Sigurliða Kristjánssonar.

\section{Heimildir}

1. Arnórsson Th, Ólafsson $\mathrm{G}$, Alfreðsson $\mathrm{H}$, Johannsson $\mathrm{KB}$, Gudbjartsson T. Ágrip erinda af vísindapingi Skurðlæknafélags Íslands og Svæfinga- og gjörgæslulæknafélags Î́slands. E 24. Vísindaping SKÍ og SLFí: Læknablaðið 2007: 93; 320.

2. Banning AP, Westaby $\mathrm{S}$, Morice MC, Kappetein AP, Moh FW, Berti S, et al. Diabetic and nondiabetic patients with left main and/or 3-vessel coronary artery disease: comparison of outcomes with cardiac surgery and paclitaxel-eluting stents. J Am Coll Cardiol 2010;55: 1067-75.

3. Durham S Ji GJLCoCS. Cohn L: Cardiac Surgery in the Adult. New York: McGraw-Hill; 2008.

4. Magee MJ, Alexander JH, Hafley G, Ferguson TB Jr, Gibson CM, Harrington RA, et al. Coronary artery bypass graft failure after on-pump and off-pump coronary artery bypass: findings from PREVENT IV. Ann Thor Surg 2008; 85: 494-500

5. Chu D, Bakaeen FG, Dao TK, LeMaire SA, Coselli JS, Huh J. On-Pump Versus Off-Pump Coronary Artery Bypass Grafting in a Cohort of 63,000 Patients. Ann Thor Surg 2009; 87: 1820-7.

6. Shroyer AL, Grover FL, Hattler B, et al. On-Pump versus Off-Pump Coronary-Artery Bypass Surgery. N Engl J Med 2009; 361: 1827-37

7. Gold JP, Wasnick J, Maldarelli W, Zhuraavlev I, Torres $\mathrm{KE}$, Condit D. Selective use of off-pump coronary bypass surgery reduces mortality and neurologic morbidity associated with high-risk coronary bypass surgery: A 400case comparative experience. Heart Surgery Forum 2004; 7:E562-E8.

8. Puskas JD, Williams WH, Mahoney EM, Huber PR, Block PC, Duke PG,et al. Off-pump vs conventional coronary artery bypass grafting: Early and 1-year graft patency, cost, and quality-of-life outcomes a randomized trial. JAMA 2004; 291: 1841-9.

9. Kobayashi J, Tashiro T, Ochi M, Yaku H, Watanabe G, Satoh T, et al. Early outcome of a randomized comparison of off-pump and on-pump multiple arterial coronary revascularization. Circulation 2005; 112: I338-I43.

10. Khan NE, De Souza A, Mister R, Flather M, Clague J, Davies S, Collins P, et al. A randomized comparison of offpump and on-pump multivessel coronary-artery bypass surgery. N Engl J Med 2004; 350: 21-8.

11. Lamy A, Devereaux PJ, Prabhakaran D, Taggart DP, $\mathrm{Hu}$ S, Paolasso E, Straka Z, et al. Off-Pump or On-Pump Coronary-Artery Bypass Grafting at 30 Days. N Engl J Med 2012; 366:1489-97.

12. Oddsson SJ, Sigurjonsson H, Helgadottir S, Sigurdsson MI, Viktorsson SA, Arnorsson Th, et al. Tengsl offitu við árangur kransæðahjáveituaðgerða. Læknablaðið 2011; 97 ; 223-8.

13. Sigurdsson MI, Helgadottir S, Ingvarsdottir IL, Viktorsson SA, Hreinsson K, Arnorsson Th, et al. Árangur kransæðahjáveituaðgerða og ósæðarlokuskipta hjá öldruðum. Læknablaðið 2012; 98: 15-8.

14. Cleveland JC, Shroyer ALW, Chen AY, Peterson E, Grover FL. Off-pump coronary artery bypass grafting decreases risk-adjusted mortality and morbidity. Ann Thor Surg 2001: 72:1 282-8

15. Ivert T. Svensk hjärtkirurgiregistret. In. Stockholm: Svensk Thoraxkirurgisk Förening; 2006.

16. Shroyer AL, Coombs LP, Peterson ED, Eiken MC, DeLong ER, Chen A, et al. The Society of Thoracic Surgeons: 30-day operative mortality and morbidity risk models. Ann Thorac Surg 2003; 75: 1856-64; discussion 64-5.

17. Zaman AG, Archbold RA, Helft G, Paul EA, Curzen NP,
Mills PG. Atrial fibrillation after coronary artery bypass surgery: a model for preoperative risk stratification. Circulation 2000; 101: 1403-8.

18. Koletsis EN, Prokakis C, Crockett JR, Dedeilias P, Panagiotou M, Panagopoulos N, et al. Prognostic factors of atrial fibrillation following elective coronary artery bypass grafting: the impact of quantified intraoperative myocardial ischemia. J Cardiothorac Surg 2011; 6: 127 .

19. Merie C, Kober L, Olsen PS, Andersson C, Jensen JS, TorpPedersen C. Risk of stroke after coronary artery bypass grafting: effect of age and comorbidities. Stroke 2012; 43: $38-43$.

20. Steingrimsson S, Gottfredsson M, Kristinsson KG, Gudbjartsson T. Deep sternal wound infections following open heart surgery in Iceland. A population-based study. Scand Cardiovasc J 2008; 42: i208-13.

21. Ingvarsdottir IL, Viktorsson SA, Hreinsson K, Sigurðsson MI, Helgadóttir S, Arnorsson Th, et al. Lokuskipti vegna ósæðarlokuprengsla á Î́slandi 2002-2006: ábendingar og snemmkomnir fylgikvillar. Læknablaðið 2011; 97: 523-7.

22. Karthik S, Grayson AD, McCarron EE, Pullan DM, Desmond MJ. Reexploration for bleeding after coronary artery bypass surgery: risk factors, outcomes, and the effect of time delay. Ann Thorac Surg 2004; 78: 527-34; discussion 34 .

23. Uffman JK, Berry BE. On-pump versus off-pump coronary artery bypass surgery: a comparison of two consecutive series. J La State Med Soc 2008; 160: 204-7.

24. Surgeons TSoT. STS National Database. In; 2009.

25. Edgerton JR, Dewey TM, Magee MJ, Herbert MA, Prince $\mathrm{SL}$, Jones KK, et al. Conversion in off-pump coronary artery bypass grafting: an analysis of predictors and outcomes. Ann Thorac Surg 2003; 76: 1138-42; discussion 42-3.

\section{ENGLISH SUMMARY}

\section{Outcome of myocardial revascularisation in Iceland}

Sigurjonsson $\mathrm{H}^{1,2}$, Helgadottir $\mathrm{S}^{1}$, Oddsson $\mathrm{S}^{1}$, Sigurdsson $\mathrm{M}^{1,2}$, Geirsson $\mathrm{A}^{1}$, Arnorsson $\mathrm{Th}^{1}$, Gudbjartsson $\mathrm{T}^{1,2}$

Introduction: In Iceland over 3500 coronary artery bypass operations have been performed, both On-Pump, using cardiopulmonary bypass and Off-Pump, surgery on a beating heart. The aim was to study their outcome.

Material and methods: This was a retrospective study on 720 consecutive patients who underwent surgical revascularisation at Landspítali - The National University Hospital of Iceland between 20022006; 513 On-Pump and 207 Off-Pump patients. Complications and operative mortality ( $<30$ days) were compared between the groups and predictors of survival identified using multivariate analysis.

Results: The number of males was significantly higher in the On-Pump group, but other risk factors of coronary artery disease, including age and high body mass index, were comparable, as were the number of distal anastomoses and EuroSCORE. The Off-Pump procedure took
25 minutes longer on average and chest tube output was significantly increased, but the amount of transfusions administered was similar. The rate of minor complications was higher in the On-Pump group. Of the major complications, stroke rates were similar in both groups (2\%) but the rate of reoperation for bleeding was higher in the On-Pump group. Mean length of hospital stay was one day longer for On-Pump patients but operative mortality was similar for both groups ( $4 \%$ vs. $3 \%, p=0.68$ ) as was 5 year survival ( $92 \%$ in both groups). In multivariate analysis both EuroSCORE and age predicted outcome of operative mortality and long term survival but type of surgery (On-Pump vs. OffPump) was not a predictive variant.

Conclusions: Outcome of myocardial revascularisation in Iceland is good as regards operative mortality and long term survival. This applies to both conventional On-Pump and Off-Pump procedures.

Key words: Coronary artery bypass graft (CABG), off-pump coronary artery bypass surgery (OPCAB), complications, operative mortality, survival, population based.

Correspondence: Tómas Guð̋bjartsson, tomasgud@landspitali.is

'Department of Cardiothoracic Surgery, Landspitali - The National University Hospital of Iceland, ${ }^{2}$ Faculty of Medicine, University of Iceland, Reykjavik, Iceland 